\title{
Pembinaan Debat Bahasa Inggris bagi Siswa Sekolah Menengah Atas Negeri 1 Moyo Utara Kabupaten Sumbawa
}

\author{
Umar $^{1 *}$, Supriadin $^{2}$, Suparman $^{2}$ \\ ${ }^{1}$ Universitas Teknologi Sumbawa, Sumbawa, Indonesia \\ ${ }^{2}$ STKIP Paracendekia N W Sumbawa, Sumbawa, Indonesia \\ *Coresponding Author: umar@uts.ac.id \\ Dikirim: 17-01-2022; Direvisi: 19-01-2022; Diterima: 20-01-2022
}

\begin{abstract}
Abstrak: Kegiatan Pengabdian Kepada Masyarakat ini bertujuan untuk memberikan pembinaan dan pelatihan teknik debat Bahasa Inggris bagi siswa SMAN I Moyo Utara Kabupaten Sumbawa. Tahapan-tahapan dalam kegiatan ini adalah (1) Planning, (2) Sosialisasi peraturan dan teknik National School Debating Championship (NSDC), (3) Pemberian materi debat bahasa Inggris yang dilakukan dengan mengenalkan tema atau topik gagasan debat yang akan diperlombakan di tingkat Propinsi Nusa Tenggara Barat dengan standar internasional, (4) Pendampingan dan pelatihan debat bahasa Inggris dengan memberikan materi terkait motion yang dilombakan, (5) Peserta pendampingan melakukan latihan pemahaman materi yang diberikan oleh pendamping, (6) Evaluasi kegiatan dilakukan dengan membuat kelompok debat, kemudian melakukan debat intra kelompok, dan (7) Pelaporan kegiatan. Berdasarkan hasil evaluasi selama kegiatan (1) Peserta didik sangat termotivasi dan percaya diri menggunakan Bahasa Inggris selama pendampingan dan pelatihan debat, dan (2) Selama berinteraksi atau komunikasi dengan Bahasa Inggris, peserta didik masih menemui hambatan terkait kekurangan vocabulary, pronunciation dan grammar used. Kegiatan ini dilakukan untuk membina dan melatih teknik debat Bahasa Inggris bagi siswa SMAN I Moyo Utara Kabupaten Sumbawa, sehingga mereka memiliki keterampilan debat dengan menggunakan Bahasa Inggris. Luaran yang akan dihasilkan dalam pengabdian kepada masyarakat ini adalah siswa mampu melakukan debat Bahasa Inggris sesuai standar internasional.
\end{abstract}

Kata Kunci: sekolah menengah atas; pembinaan debat; bahasa Inggris

Abstract: This Community Service activity aims to provide coaching and training in English debating techniques for students of SMAN I Moyo Utara, Sumbawa Regency. The stages offer some activities are (1) Planning, (2) Socialization of National School Debating Championship (NSDC) rules and techniques, (3) Providing English language debate material by introducing the theme or topic of debate ideas that will be contested at the level of West Nusa Tenggara Province with international standards, (3) Mentoring and training in English debate by providing material related to the ideas which contested, (4) Mentoring participants practice understanding the material provided by the facilitator, (5) Evaluation of activities is carried out by creating debate groups, then conducting intra-group debates, and (7) Report Activities. Based on the results of the evaluation during the activity (1) Students are highly motivated and confident in using English during mentoring and debate training, and (2) During interacting or communicating with English, students still encounter obstacles related to lack of vocabulary, pronunciation and grammar used. This activity is carried out to foster and train English debate techniques for students of SMAN I Moyo Utara, Sumbawa Regency, so that they have debate skills using English. Outcomes that will be produced in this community service, students are able to debate English according to international standard.

Keywords: senior high school; debating coaching; English

@2022 Bima Abdi (https://jurnal.bimaberilmu.com/index.php/ba-jpm) 


\section{PENDAHULUAN}

Sekolah Menengah Atas Negeri (SMAN) 1 Moyo Utara merupakan salah satu sekolah menengah atas di Kabupaten Sumbawa. Sekolah ini berlokasi di Kabupaten Sumbawa sebagai salah satu pintu masuk jalur ke Pulau Moyo dan Pulau Satonda. Sebagai area jalur wisata kelas dunia, perangkat pembelajaran sekolah ini berbenah, terutama pembelajaran Bahasa Inggris. Pembelajaran Bahasa Inggris memiliki empat keterampilan berbahasa, salah satunya adalah keterampilan berbicara. Keterampilan berbicara merupakan salah satu keterampilan yang harus dikuasai oleh para pembelajar bahasa Asing. Sebagaimana yang diungkapkan oleh Ratnawati et al., 2018; Ruspa, 2019; Yunita et al., 2017; Yenni et al., 2021) yang menyatakan bahwa keterampilan berbicara merupakan salah satu indikator terpenting untuk keberhasilan siswa dalam belajar bahasa Inggris. Berbicara erat kaitanya dengan kemampuan seseorang berpikir dan bernalar untuk memberikan pemahaman yang baik kepada lawan bicara. Senada dengan Hotmaria (2021) yang menyatakan bahwa dengan penguasaan keterampilan berbicara yang baik, siswa dapat mengkomunikasikan ideide mereka, baik di sekolah maupun dengan penutur asing, serta dapat menjaga hubungan baik dengan orang lain. Hal ini didukung oleh Rahayu \& Astutie, (2018) bahwa berbicara merupakan persoalan tersendiri yang harus dikuasai oleh siswa, yang menjadi perpaduan kemampuan antara otak, olah kata atau kalimat dan kemampuan mendengarkan.

Guru Bahasa Inggris SMAN 1 Moyo Utara menggunakan metode pembelajaran kontekstual dalam mengajarkan siswa-siswanya untuk mempercepat berinteraksi atau berkomunikasi dengan keterampilan bahasa Inggris. Metode pembelajaran kontekstual yang digunakan adalah debat. Hal ini senada dengan Sriwahyuni et al. (2013) yang menyatakan bahwa salah satu metode pembelajaran yang bisa menerapkan pendekatan kontekstual sesuai dengan KTSP dan pembelajaran kekinian adalah dengan pembelajaran kontekstual melalui debat. Implementasi kelas debat juga sesderhana, yaitu dengan membagi 2 kelompok, kemudian masing-masing kelompok diberikan sebuah topik. Senada dengan Widarmana et al. (2015) yang menyatakan bahwa kebanyakan yang terjadi di kelas debat adalah sangat sederhana, dengan membagi siswa menjadi dua kelompok, yaitu kelompok afirmatif dan negatif. Kemudian masing-masing kelompok diberikan sebuah topik yang akan diperdebatkan.

Kemampuan debat merupakan kemampuan yang dimiliki oleh seseorang dalam gaya berkomunikasi dengan komunikan. Hal ini senada dengan Nurfitriah et al., (2019) yang menyatakan bahwa debat dipercaya bisa memberikan kesempatan kepada siswa untuk berbicara dalam Bahasa Inggris, berlatih mengemukakan pendapat di depan umum, dan melatih kepercayaan diri siswa untuk berbicara Bahasa Inggris. Hal ini didukung juga oleh Rossydi, (2019) yang menyatakan bahwa Individu dapat menggunakan debat untuk mencapai keputusan dalam pikiran mereka sendiri; sebagai alternatif, individu atau kelompok dapat menggunakannya untuk membawa orang lain ke cara berpikir mereka.

Selanjutnya, Sriwahyuni et al. (2013) menyatakan bahwa ada tiga hal yang selalu berkaitan dengan debat, yaitu 1) gaya komunikasi. Ini berkaitan dengan aplikasi fungsi-fungsi bahasa yang bisa menentukan posisi pembicara seperti expressing agreement dan disagreement, denying someone or something, expressing ideas or opinion dan yang lainnya. 2) mengkomunikasikan suatu permasalahan. Ini 
berarti bahwa metode debat memberikan kesempatan kepada siswa untuk mengeksplorasikan diri dan pengetahuannya yang dihasilkan dari proses inquiry sebelumnya atau lebih dikenal dengan case building, dan 3) mempertimbangkan aturan-aturan tertentu. Dalam penerapannya, metode debat memiliki aturan prosedural tertentu sehingga memerlukan kesiapan yang matang.

Prinsip debat yang dilaksanakan berbeda-beda sesuai jenis debat yang dilakoni. Debat kompetitif, debat perlementer dan sebagainya merupakan contoh debat yang sering dilaksanakan. Debat kompetitif adalah debat dalam bentuk permainan yang biasa dilakukan di tingkat sekolah dan universitas. Dalam hal ini, debat dilakukan sebagai pertandingan dengan aturan yang jelas dan ketat antara dua pihak yang masing-masing mendukung dan menentang sebuah pernyataan. Debat disaksikan oleh satu atau beberapa orang juri yang ditunjuk untuk menentukan pemenang dari sebuah debat. Pemenang dari debat kompetitif adalah tim yang berhasil menunjukkan pengetahuan dan kemampuan debat yang lebih baik. Salah satu lomba yang diadakan setiap tahun yang diadakan oleh Kementerian Pendidikan Nasional baik di tingkat regional maupun nasional adalah National Schools Debating Championship (NSDC) yang merupakan lomba pidato yang diikuti oleh siswa-siswa SMA dan sederajat, Direktorat Pembinaan Sekolah Menengah Atas Direktorat Jenderal Pendidikan Dasar dan Menengah Kementerian Pendidikan dan Kebudayaan, (2019).

Terkait adanya kegiatan lomba National Schools Debating Championship (NSDC) yang diadakan oleh Kementerian Pendidikan Nasional, tim guru Bahasa Inggris SMAN 1 Moyo Utara ikut berpartisipasi dalam kegiatan tersebut. Sebagai ajang latihan kemampuan keterampilan berinteraksi atau berkomunikasi menggunakan Bahasa Inggris yang berstandar internasional. Hasil evaluasi tim guru Bahasa Inggris terkait kemampuan siswanya dalam berdebat masih di bawah standar untuk ikut dalam kegiatan National Schools Debating Championship (NSDC). Di sisi lain, sekolah tidak memiliki SDM untuk melatih siswa sehingga mereka mampu bertanding secara maksimal. Berdasarkan hasil evaluasi tersebut, siswa SMAN 1 Moyo Utara membutuhkan pembinaan dan pelatihan oleh pembina di luar sekolah yang memiliki pengalaman terkait kegiatan dimaksud. Universitas Teknologi Sumbawa dan STKIP Paracendekia NW Sumbawa merupakan perguruan tinggi di Nusa Tenggara Barat yang sudah memiliki nama yang cukup dikenal di kalangan nasional dalam hal debat Bahasa Inggris tingkat perguruan tinggi baik tingkat lokal, regional maupun nasional.

Kegiatan pengabdian kepada masyarakat ini bertujuan untuk membina dan melatih debat untuk meningkatkan kemampuan debat dalam Bahasa Inggris bagi siswa SMAN 1 Moyo Utara. Luaran yang ditargetkan adalah terbentuknya wadah bagi siswa sekolah mitra untuk meningkatkan kemampuan Bahasa Inggris mereka melalui debat dan terpilihnya perwakilan siswa untuk mengikuti lomba debat. Para guru pengajar Bahasa Ingggris setelah pelatihan ini diharapkan akan memiliki pengetahuan pengelolaan kegiatan ekstrakurikuler debat Bahasa Inggris.

\section{METODE PELAKSANAAN KEGIATAN}

Kegiatan Pengabdian kepada Masyarakat dengan judul Pembinaan Debat Bahasa Inggris bagi Siswa Sekolah Menengah Atas (SMAN) 1 Moyo Utara Kabupaten Sumbawa yang beralamat di Jalan Batu Tamin, Kode Pos 84381, Kecamatan Moyo Utara. Kabupaten Sumbawa. Kegiatan ini diikuti oleh siswa 
peserta debat SMA Negeri 1 Moyo Utara yang dibina dan dilatih oleh dosen Universitas Teknologi Sumbawa dan STKIP Paracendekia NW Sumbawa. Adapun tahapan pelaksanaan pengabdian berupa pembinaan dan pelatihan debat dalam Bahasa Inggris adalah sebagai berikut: (1) planning (2) sosialisasi peraturan dan teknik National Schools Debating Championship (NSDC), (3) pemberian materi debat bahasa Inggris yang dilakukan dengan mengenalkan tema atau motion debat yang akan diperlombakan di tingkat Propinsi Nusa Tenggara Barat, (4) pendampingan dan pelatihan debat Bahasa Inggris dengan memberikan materi terkait motion yang dilombakan, (5) peserta pendampingan melakukan latihan pemahaman materi yang diberikan oleh pendamping, (6) evaluasi kegiatan dilakukan dengan membuat kelompok debat, kemudian melakukan deba antar kelompok, dan (7) pelaporan hasil kegiatan. Hal ini dapat dilihat pada gambar 1 di bawah ini.

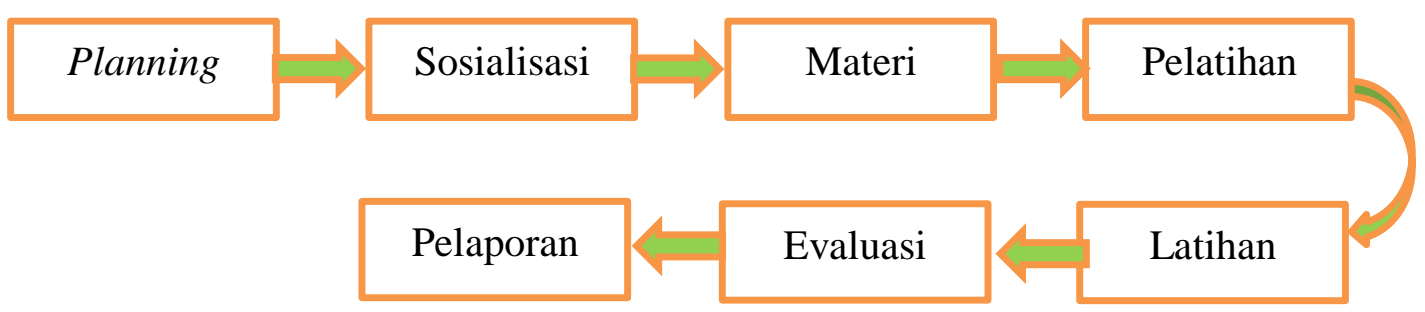

Gambar 1. Tahapan Pembinaan dan Pelatihan

\section{IMPLEMENTASI KEGIATAN DAN PEMBAHASAN}

PKM pembinaan dan pelatihan debat Bahasa Inggris bagi siswa Sekolah Menengah Atas (SMAN) 1 Moyo Utara, Kabupaten Sumbawa dimulai sejak bulan Mei s/d bulan Juni 2021. Kegiatan PKM ini memiliki beberapa tahapan pelaksanaan. Adapun tahapan implementasi kegiatan tersebut yaitu;

Tahap (1) planning kegiatan;

Kegiatan PKM terkait pembinaan dan pelatihan debat Bahasa Inggris bagi siswa Sekolah Menengah Atas (SMAN) 1 Moyo Utara, Kabupaten Sumbawa. Pada tahap ini tim English teaching berdiskusi dengan tim Pembina terkait analisis kebutuhan pelajar dan pengajar selama mengimplementasikan kegiatan pendampingan, seperti; persiapan materi ajar, dan ruangan belajar;

Tahap (2) sosialisasi kegiatan;

Pada tahap ini tim pendamping mensosialisasikan terkait tata cara atau peraturan dan teknik pelaksanaan National Schools Debating Championship (NSDC) pada tataran Sekolah Menengah Atas. Seperti; metode seleksi sistem turnamen, yang terdiri dari 2 babak, yaitu babak penyisihan (Preliminary Rounds) kemudian babak eliminasi (Octofinal sampai dengan Final Rounds), penentuan tim yang akan menjadi top 16, mekanisme penilaian yaitu Substantive Speech dan replay speech, dan kriteria penilaian yang terdiri dari isi [content], penyampaian [style] dan strategi [strategy]. Urutan berbicara dalam debat, mulai dari pembicara 1 tim affirmative sampai yang terakhir pada reply speaker pada tim negative dan ditutup oleh reply speaker dari tim affirmative. Tim affirmative (government) harus bertahan dan memberikan argumenargumen yang membangun motion. Tim ini mempunyai wewenang mendefinisikan motion sebagai suatu definisi yang beralasan. Tim negative (opposition) harus 
bertindak menentang dan memberikan argument yang bersifat melawan atau menentang motion yang diberikan oleh tim affirmative. Berikut tabel mekanisme penilaian diambil dari pedoman kegiatan National Schools Debating Championship (NSDC) 2019.

Tabel 1. Penilaian Substantive Speech

\begin{tabular}{|l|l|l|l|l|}
\hline Standard & $\begin{array}{l}\text { Overall } \\
(/ \mathbf{1 0 0})\end{array}$ & $\begin{array}{l}\text { Style } \\
(/ \mathbf{4 0})\end{array}$ & $\begin{array}{l}\text { Content } \\
(\mathbf{/ 4 0})\end{array}$ & $\begin{array}{l}\text { Strategy } \\
(/ \mathbf{2 0})\end{array}$ \\
\hline Exceptional & 80 & 32 & 32 & 16 \\
\hline Excellent & $76-79$ & 31 & 31 & $15-16$ \\
\hline Extremely Good & $74-75$ & 31 & 31 & $15-16$ \\
\hline Very Good & $71-73$ & 30 & 30 & 15 \\
\hline Good & 70 & 28 & 28 & 14 \\
\hline Satisfactory & $67-69$ & 27 & 27 & $13-14$ \\
\hline Competent & $65-66$ & 26 & 26 & 13 \\
\hline Pass & $61-64$ & 25 & 25 & $12-13$ \\
\hline Improvement Needed & 60 & 24 & 24 & 12 \\
\hline
\end{tabular}

Tabel 2. Penilaian Replay Speech

\begin{tabular}{|l|l|l|l|l|}
\hline Standard & $\begin{array}{l}\text { Overall } \\
(/ \mathbf{5 0})\end{array}$ & $\begin{array}{l}\text { Style } \\
(/ \mathbf{2 0})\end{array}$ & $\begin{array}{l}\text { Content } \\
(/ \mathbf{2 0})\end{array}$ & $\begin{array}{l}\text { Strategy } \\
(/ \mathbf{1 0})\end{array}$ \\
\hline Exceptional & 40 & 16 & 16 & 8 \\
\hline Very Good to Excellent & $36-39$ & 15 & 15 & 7.5 \\
\hline Good & 35 & 14 & 14 & 7 \\
\hline Pass to Satisfactory & $31-34$ & 13 & 13 & 6.5 \\
\hline Improvement Needed & 30 & 12 & 12 & \\
\hline
\end{tabular}

Tahap (3) pemberian materi debat;

Pada tahap ini tim pendamping menyiapkan materi yang diajarkan selama kegiatan pendampingan. Seperti; pemilihan materi isu-isu terkini, menyusun materi untuk tim afirmatif dan tim opposition. Kemudian materi yang sama ditukar pada tim yang berbeda.

Tahap (4) pelatihan debat;

Pada fase ini, setelah pembagian materi, pendamping mulai mengatur sitem debat. Seperti; tim afirmatif sebagai pembicara pertma kemudian disanggah oleh tim opposition. Tahap ini akan berulang pada setiap materi debat yang baru. Kemudian materi tim afirmatif digunakan oleh tim opposition dan begitupun sebaliknya.

Tahap (5) latihan debat;

Pada tahap ini, setelah pelatihan debat, pendamping meminta peserta didik untuk melatih diri sebagai debater yang nyata. Jadi kegiatan ini mempersiapkan peserta untuk siap menjadi komputitor debat. Semua isu-isu terbaru akan dituangkan sebagai ajang latihan dalam debat. Sehingga mereka mampu menggunakan keterampilan berbahasa Inggris maksimal dan sesuai standar. 
Tahap (6) evaluasi kegiatan;

Pada tahap ini, pendamping mengevaluasi kemampuan peserta didik dalam penimplemnetasian materi debat yang sudah diberikan. Seperti; kemampuan memberikan argument sanggahan ketika tim affirmative membuat sebuah argument. Kemudian sanggahan mampu melumpuhkan statement tim affirmative dan begitupun sebaliknya. Disamping itu, pendamping juga mengevalusi penggunaan pronunciation dan grammatical used selama mereka latihan sampai pada tahap evaluasi.

Tahap (7) laporan kegiatan;

Pada tahap ini, pendamping melaporkan terkait kemajuan dan kekurangan selama proses pendampingan kegiatan debat bahasa Inggris. Terkait kemajuan, seperti; peserta didik memiliki motivasi dan kepercayaan diri dalam menggunakan bahasa Inggris. Dan terkait kelemahan, seperti; kekuranagn kosa kata bahasa Inggris pronunciation dan grammatical used peserta yang dapat mempengaruhi selama debat.

Ketercapaian target materi pada kegiatan PKM pendampingan dan pelatihan debat Bahasa Inggris bagi siswa SMAN 1 Moyo Utara tergolong baik karena materi pendampingan telah dapat disampaikan secara keseluruhan dan dapat dipahami dengan baik oleh peserta pelatihan. Meskipun masih ada kekurangan terkait content Bahasa Inggris itu sendiri. Pemahaman Bahasa Inggris dapat dipahami dengan baik apabila pelatih atau guru dapat memanipulasi atau menciptakan pembelajaran dan pelatihan yang efektif dengan menerapkan penggunaan Bahasa Inggris yang baik (Amiruddin \& Jannah, 2021).

\section{KESIMPULAN}

Dari hasil dan pelaksanaan kegiatan Pengabdian Kepada Masyarakat pendampingan dan pelatihan debat Bahasa Inggris bagi siswa SMAN 1 Moyo Utara dapat disimpulkan sebagai berikut; 1) PKM ini diselenggarakan dalam tujuh tahapan; planning, sosialisasi, pemberian materi, pelatihan, latihan, evaluasi dan laporan, semua periode tahapan terlaksana dengan baik dan tuntas; 2) Peserta didik sangat termotivasi dan percaya diri menggunakan Bahasa Inggris selama pendampinag dan pelatihan debat; 3) Selama berinteraksi atau komunikasi dengan bahasa Inggris, peserta didik masih menemui hambatan terkait kekurangan vocabulary, pronunciation dan grammar used.

\section{DAFTAR PUSTAKA}

Amiruddin, M., \& Jannah, U. R. (2021). Pelatihan Bahasa Inggris Bagi Anak Usia Dini di Daerah Terpencil Kecamatan Pademawu Pamekasan. Bima Abdi: Jurnal Pengabdian Masyarakat, 1(1), 18-22.

Direktorat Pembinaan Sekolah Menengah Atas Direktorat Jenderal Pendidikan Dasar dan Menengah Kementerian Pendidikan dan Kebudayaan. 2019. Pedoman Kegiatan National Schools Debating Championship (NSDC). Jakarta: Kemdikbud.

Hotmaria. (2021). Upaya Meningkatkan Keterampilan Berbicara Bahasa Inggris Pada Materi Pengandaian Diikuti Perintah/Saran Menggunakan Strategi 
Pembelajaran Three Step Interview. Journal of Education Action Research, 5(1), 1-9.

Nurfitriah, Asy'ari, M. A., Adriyati, R., \& Suwaji. (2019). Pelatihan Debat dalam Bahasa Inggris untuk Siswa SMA PGRI 6 Banjarmasin. Jurnal Impact: Implementation and Action, 1(2), 146-151.

Rahayu, Y., \& Astutie, E. (2018). Peningkatan Kemampuan Berbicara Bahasa Inggris Siswa Kelas VII SMP Negeri I Kota Blitar Melalui Games (Kalender). Jurnal Pendidikan, 2(1), 45-56

Ratnawati, S. R., Yuliasri, I., \& Hartono, R. (2018). Enhancing the Students' Speaking Skill Using Three Step Interview and Numbered Heads Together. Language Circle: Journal of Language and Literature, 12(2), 173-181.

Ruspa, A. R. (2019). Penerapan Model Inquiri pada Pembelajaran Menulis Karangan Eksposisi Siswa Kelas VIII SMP Negeri 1 Sabbang Kabupaten Luwu Utara. Jurnal Studi Guru Dan Pembelajaran, 2(3), 210-220.

Rossydi, A. (2019). Penggunaan Debat Bahasa Inggris Untuk English as a Foreign Language Students dalam Pengajaran Speaking. Airman: Jurnal Teknik dan Keselamatan Transportasi, 2(2), 209-222.

Sriwahyuni, I. A., Dantes, N., \& Marhaeni, A. I. (2013). Pengaruh Implementasi Metode Debat Terhadap Keterampilan Berbicara Bahasa Inggris Ditinjau dari Minat Belajar Kelas XI IPA SMA Negeri 2 Amlapura. e-Journal Program Pascasarjana Universitas Pendidikan Ganesha, 4, 1-13.

Widarmana, I. G., Yudana, I. M., \& Natajaya, I. N. (2015). Pengahruh Metode Debat Terhadap Kemampuan Berbicara dalam Bahasa Inggris Ditinjau dari Ekspetasi Karir Bahasa Inggris pada Siswa Kelas XII SMA N 1 Kerambitan. e-Journal Program Pascasarjana Universitas Pendidikan Ganesha, 6(1), 1-11.

Yenni, E., Tenerman, T., \& Sinaga, C. N. A. (2021). Peningkatan Kemampuan Berbahasa Inggris Masyarakat Lokal terhadap Pariwisata Desa Lumban SuhiSuhi Toruan. Bima Abdi: Jurnal Pengabdian Masyarakat, 1(2), 83-87.

Yunita, Y., Fitri, F., \& Zulfahita, Z. (2017). Peningkatan Keterampilan Membaca Ekstensif Menggunakan Model Pembelajaran Reciprocal Teaching pada Siswa Kelas VIII D MTs Negeri Singkawang Tahun Ajaran 2016/2017. JP-BSI (Jurnal Pendidikan Bahasa Dan Sastra Indonesia), 2(1), 12. 